\title{
Characterization and Genomic Analysis of Novel Bacteriophage ФCS01 Targeting Cronobacter sakazakii
}

\author{
Gyeong-Hwuii Kim, Jaegon Kim, Ki-Hwan Kim, Jin-Sun Lee, Na-Gyeong Lee, Tae-Hyun Lim, and Sung-Sik Yoon*
}

Department of Biological Science and Technology, Yonsei University, Wonju 26493, Republic of Korea

\author{
Received: December 26, 2018 \\ Revised: April 8, 2019 \\ Accepted: April 9, 2019 \\ First published online \\ April 12, 2019 \\ ${ }^{*}$ Corresponding author \\ Phone: +82-33-760-2251; \\ Fax: +82-33-760-5576; \\ E-mail: sungsik@yonsei.ac.kr \\ pISSN 1017-7825, eISSN 1738-8872 \\ Copyright(C) 2019 by \\ The Korean Society for Microbiology \\ and Biotechnology
}

Cronobacter sakazakii is an opportunistic pathogen causing serious infections in neonates. In this study, a bacteriophage ФCS01, which infects C. sakazakii, was isolated from swine feces and its morphology, growth parameters, and genomic analysis were investigated. Transmission electron microscopy revealed that $\Phi C S 01$ has a spherical head and is $65.74 \mathrm{~nm}$ in diameter with a $98.75 \mathrm{~nm}$ contracted tail, suggesting that it belongs to the family Myoviridae. The major viral proteins are approximately $71 \mathrm{kDa}$ and $64 \mathrm{kDa}$ in size. The latent period of ФCS01 was shown to be $60 \mathrm{~min}$, and the burst size was $90.7 \mathrm{pfu}$ (plaque-forming units)/ infected cell. Bacteriophage $\Phi \mathrm{CS} 01$ was stable at $4-60^{\circ} \mathrm{C}$ for $1 \mathrm{~h}$ and lost infectivity after $1 \mathrm{~h}$ of heating at $70^{\circ} \mathrm{C}$. Infectivity remained unaffected at $\mathrm{pH} 4-9$ for $2 \mathrm{~h}$, while the bacteriophage was inactivated at $\mathrm{pH}<3$ or $>10$. The double-stranded $\Phi C S 01$ DNA genome consists of 48,195 base pairs, with 75 predicted open reading frames. Phylogenetic analysis is closely related to that of the previously reported C. sakazakii phage ESP2949-1. The newly isolated ФCS01 shows infectivity in the host bacterium C. sakazakii, indicating that it may be a promising alternative to antibacterial agents for the removal of $C$. sakazakii from powdered infant formulas.

Keywords: Bacteriophages, Cronobacter sakazakii, Myoviridae, genomic analysis, food safety

\section{Introduction}

Cronobacter species, formerly known as Enterobacter sakazakii [1] were first isolated in 1980 [2] and are gramnegative, rod-shaped opportunistic pathogens of the family Enterobacteriacea [3]. These species are ubiquitous and have been isolated from food and environments, including water, soil, processed foods, and fresh produce [4].

Cronobacter sakazakii is associated with necrotizing enterocolitis and meningitis and is a contaminant in powdered infant formula (PIF) [5]. Contaminated PIF is a major cause of neonatal infection [6], and pathogenic bacterial contamination of PIF can be caused by improper product storage during the manufacture process [7]. Neonates and infants have weak immunity and C. sakazakii infection can cause more serious problems than in adults [8]. Therefore, pathogen-specific microbial control measures are required.

At present, antibiotics are widely used to prevent infection by pathogenic C. sakazakii [9]. Nevertheless, the emergence of antibiotic-resistant bacteria has caused serious problems for both biotechnological and medical applications [10]. In addition, C. sakazakii demonstrated antibiotic resistance in antibiotic susceptibility tests [11]. Therefore, a safe biocontrol agent that can control C. sakazakii and replace antibiotics should be developed.

In 2006, the US Food and Drug Administration (FDA) approved the use of purified bacteriophages as food additives [11]. In a previous study, the complete genomic sequence of a bacteriophage infecting C. sakazakii was reported, and phage genome analysis revealed no toxicityrelated genes encoding toxic agents and toxins [11-18]. The use of bacteriophages as biological agents is a potential alternative to the use of antibiotics [19]. A bacteriophage is a virus that uses bacterial cells as hosts and selectively infects target bacteria to destroy bacterial cells [19]. This lytic activity makes bacteriophages a promising substitute for antibiotics [20].

In this study, ФCS01, a bacteriophage that infects the pathogenic bacterium C. sakazakii was isolated from swine 
feces. Morphological and growth characteristics of the phage were investigated, and genetic characteristics were assessed using next-generation sequencing. The identified phage has potential applications as an alternative to antibiotics for use as a biological control agent in the food industry.

\section{Materials and Methods}

\section{Host Bacterial Strains and Growth Conditions}

The host bacterial strain used in this study, Cronobacter sakazakii ATCC 29544, was provided by the American Type Culture Collection (ATCC). Brain heart infusion (BHI, Becton Dickinson, USA) broth and agar were used to culture the strain. Standard double-layer agar technique [21] was employed to generate a single plaque and calculate phage concentration.

\section{Isolation and Propagation of the Phage}

Bacteriophages were isolated from swine feces obtained from a pig farm located in Gangwon Province, Republic of Korea. Each sample was diluted 1:10 (w/v) in SM buffer $(50 \mathrm{mmol} / \mathrm{l}$ Tris- $\mathrm{HCl}$ [pH 7.5], $0.1 \mathrm{~mol} / 1 \mathrm{NaCl}$, and $\left.8 \mathrm{mmol} / 1 \mathrm{MgSO}_{4} \cdot 7 \mathrm{H}_{2} \mathrm{O}\right)$. The suspension was centrifuged at 3,000 $\times g$ for $20 \mathrm{~min}$. The supernatant was filtered using a $0.45 \mu \mathrm{m}$ membrane filter (Dismic; Advantec, Japan). One hundred microliters of filtered supernatant were mixed with $100 \mu \mathrm{l}$ of exponential phase C. sakazakii (optical density at $\left.600 \mathrm{~nm}\left[\mathrm{OD}_{600}\right]=0.4\right)$ and $5 \mathrm{ml}$ of top agar $(0.7 \%$ agar in $\mathrm{BHI}$ broth). The mixture was poured into a petri dish containing $1.5 \% \mathrm{BHI}$ agar and incubated at $37^{\circ} \mathrm{C}$ overnight. An individual clear plaque was picked from the overlaid agar with a sterile pipette tip, resuspended in $500 \mu \mathrm{l}$ of SM buffer, and double-layer agar technique was repeated [22].

\section{High-Titer Preparation of the Phage}

Host single colonies were resuspended in $100 \mathrm{ml}$ of $\mathrm{BHI}$ and incubated at $37^{\circ} \mathrm{C}$ with shaking at $160 \mathrm{rpm}$. When the culture reached $\mathrm{OD}_{600}=0.4$, it was centrifuged at $4,000 \times g$ for $10 \mathrm{~min}$. Pelleted cells were collected and resuspended in $3 \mathrm{ml}$ of $\mathrm{SM}$ buffer. Phages were added to the suspension at MOI of 1.0 and mixed rapidly. After incubation for $20 \mathrm{~min}$ at $37^{\circ} \mathrm{C}$ with intermittent shaking, the suspension was added to $500 \mathrm{ml}$ of BHI and incubated overnight. Chloroform was added to a concentration of $2 \%(10 \mathrm{ml})$, and the culture was further incubated at $37^{\circ} \mathrm{C}$ with shaking for $30 \mathrm{~min}$. Next, the culture was centrifuged at 11,000 $\times g$ for $10 \mathrm{~min}$ at $4^{\circ} \mathrm{C}$, and the supernatant was filtered using a syringe filter with a $0.45 \mu \mathrm{m}$ pore size (Advantec). Solid polyethylene glycol (PEG 8000) was added to the suspension to a final concentration of $10 \%(\mathrm{w} / \mathrm{v})$, and the mixture was cooled on ice for $2 \mathrm{~h}$. The lysate was centrifuged at 110,000 $\times g$ for $100 \mathrm{~min}$, and the supernatant was discarded. The pellet was resuspended in $8 \mathrm{ml}$ of SM buffer, and the same volume of chloroform was added. The mixture was vortexed for $30 \mathrm{~s}$ and then centrifuged at 3,000 $\times g$ for
$15 \mathrm{~min}$ at $4^{\circ} \mathrm{C}$. The supernatant containing the bacteriophage particles was recovered and filtered using a syringe filter with $0.45 \mu \mathrm{m}$ pore size. Phages were purified using the standard bacteriophage purification method [23].

\section{Transmission Electron Microscopy (TEM)}

Morphology was observed under a transmission electron microscope, JEOL JEM-2100F FE-TEM (KBSI, Korea), at 200 kV. A high-titer phage solution containing $10^{8}$ plaque-forming units (pfu) was negatively stained with $2 \%(\mathrm{w} / \mathrm{v})$ uranyl acetate. The phage particles were placed on a carbon coating grid and dipped into distilled water containing a drop of $2 \%$ uranyl acetate. The 200-mesh grids (Gatan, USA) were coated with a collodion film prepared from $2 \%$ collodion in amyl acetate and used to absorb carbon film fragments with phage particles. After air drying for $10 \mathrm{~min}$, grids were subjected to TEM. Images of negatively stained phage particles were taken using a one-view camera (Gatan) at $100,000 \times$ and $150,000 \times$ magnification.

\section{SDS-PAGE Analysis}

For SDS-PAGE (sodium dodecyl sulfate-polyacrylamide gel electrophoresis), $40 \mu \mathrm{l}$ of a phage solution containing $10^{8} \mathrm{pfu}$ was added to $10 \mu \mathrm{l}$ of $5 \times$ sample buffer $(312.5 \mathrm{mmol} / 1$ Tris- $\mathrm{HCl}[\mathrm{pH}$ 6.8 ], $50 \%$ glycerol, $5 \%$ SDS, $2 \% \beta$-mercaptoethanol, and $0.05 \%$ bromophenol blue; Elpis Biotech, Korea). The mixture was heated at $95^{\circ} \mathrm{C}$ for $5 \mathrm{~min}$, and $20 \mu \mathrm{l}$ of the mixture was subjected to electrophoresis at $20-40 \mathrm{mV}$ in a $15 \%$ polyacrylamide gel. The gel was stained with Coomassie Brilliant Blue G250 (Bio-Rad Laboratories, USA) for protein visualization [24].

\section{One-Step Growth Curve Analysis}

For one-step growth curve analysis, $5 \mathrm{ml}$ of $C$. sakazakii culture in the exponential phase $\left(\mathrm{OD}_{600}=0.4\right)$ was centrifuged at $4,000 \times g$ for $10 \mathrm{~min}$. The pellet was resuspended in $1 \mathrm{ml}$ of BHI broth. The phage solution was added to the suspension at a MOI of 0.1 . The mixture was incubated at $37^{\circ} \mathrm{C}$ for $30 \mathrm{~min}$ and then centrifuged at $11,000 \times g$ for $10 \mathrm{~min}$. The pellet was resuspended in $10 \mathrm{ml}$ of BHI broth. The phage concentration in the solution was measured at $10 \mathrm{~min}$ intervals for $100 \mathrm{~min}$ using the double-layer agar technique [25].

\section{Temperature and $\mathrm{pH}$ Stability of Phage Infectivity}

One milliliter of phage suspension containing $10^{7} \mathrm{pfu}$ was incubated at $4,10,20,30,37,50,60$, or $70^{\circ} \mathrm{C}$ for $1 \mathrm{~h}$. The phage concentration was then measured using the double-layer agar technique. To assay the stability at various $\mathrm{pH}$ levels, the $\mathrm{pH}$ of the BHI broth was adjusted to $\mathrm{pH} 2-12$. One hundred microliters of the phage suspension with a titer of $10^{9} \mathrm{pfu}$ was inoculated into $900 \mu \mathrm{l}$ of the $\mathrm{pH}$-adjusted media to obtain a final concentration of $10^{8} \mathrm{pfu}$. After incubation at $37^{\circ} \mathrm{C}$ for $2 \mathrm{~h}$, phage concentration was determined using the same double-layer agar technique. The experiment was conducted three times. The results are reported as the mean of three observations \pm standard deviation [12]. 


\section{Whole-Genome Sequencing}

Phage DNA was purified using the Phage DNA Isolation Kit (Norgen Biotek, Canada) and subjected to next-generation sequencing using a HiSeq 4000 instrument (Illumina, Korea, Macrogen). A DNA fragment library was constructed with the TruSeq DNA PCR Free Library Preparation Kit (Illumina). A de novo assembly was generated in the SOAPdenovo software and MEGA 6 was used for ORF prediction for the whole genome. The genome sequence was compared with other genomes in GenBank via the BLAST program (http://blast.ncbi.nlm.nih.gov/) and Mauve analysis software (http://darlinglab.org). The wholegenome sequence of ФCS01 was deposited in the NCBI database (GenBank accession number MH845412).

\section{Phylogenetic Tree Construction}

The evolutionary history of the bacteriophage was inferred using the neighbor-joining method, on the basis of the major capsid protein sequences of the isolated phage and 18 additional phages infecting Cronobacter. The percentage of replicate trees in which associated taxa clustered together in 500 bootstrap repetitions is shown next to the branches. Codon positions included were the first, second, and third positions and noncoding sites. All positions containing gaps and missing data were eliminated. There were 764 positions in the final dataset. Evolutionary analyses were conducted using MEGA 6 software (http://www.megasoftware.net).

\section{Host-Range Test}

To determine the host range of $\Phi C S 01$, plaque assays were performed. Each of the 12 different hosts were inoculated into $5 \mathrm{ml}$ of soft agar $(0.7 \%)$ and poured onto agar plates. Ten microliters of phage-titer solution were spotted onto the top agar plate and incubated at $37^{\circ} \mathrm{C}$ for overnight. After incubation, the appearance of lysis zones was examined. The lysis activity of the phage was classified as clear (+) and no reaction (-). For hostrange testing, Enterobacter and other strains were obtained from KCTC (Korean Collection for Type Cultures) or ATCC (American Type Culture Collection) [12].

\section{Results and Discussion}

\section{Morphological Analysis}

Purified ФCS01 was examined by transmission electron microscopy (TEM) (Fig. 1). The diameter of the quasispherical head with icosahedral symmetry was $65.74 \mathrm{~nm}$, and the length of the rigid tail was $98.75 \mathrm{~nm}$. In addition, ФCS01 was observed to have a non-contracted tail and contracted tail, and with a sheath-like structure on the tail. The tail fibers are difficult to observe due to the resolution of TEM, but ORF annotation results indicate the existence of tail fibers (Table 1).

Another Cronobacter sakazakii bacteriophage, PBES02,
A

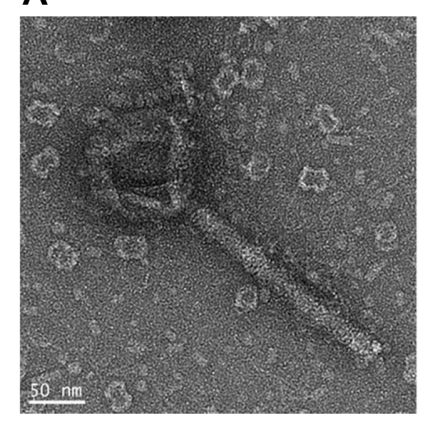

B

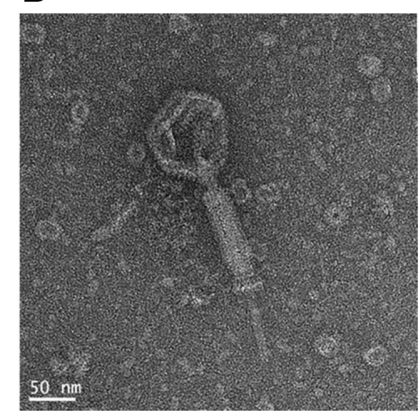

Fig. 1. Transmission electron micrographs (TEM) showing the morphology of $\Phi \mathrm{CS} 01$.

Scale bars in the lower left corners represent $50 \mathrm{~nm}$. (A) Non-contracted tail. (B) Contracted tail.

which belongs to the Myoviridae family, has a spherical head of $90 \mathrm{~nm}$ and a rigid tail of $130 \mathrm{~nm}$ [12]. Compared with PBES02, the head diameter of $\Phi C S 01$ is $24.26 \mathrm{~nm}$ smaller and the tail is $31.25 \mathrm{~nm}$ shorter, but the ratio of head to tail is similar for both phages. Based on its morphological characteristics, ФCS01 was determined to also belong to the Myoviridae family of the order Caudovirales.

\section{Characterization of $\Phi$ CS01}

Purified ФCS01 was stained with Coomassie blue and analyzed using sodium dodecyl sulfate-polyacrylamide gel electrophoresis (SDS-PAGE) (Fig. 2A). The results suggest that the bacteriophage has two major proteins and four minor proteins; and the $71 \mathrm{kDa}$ protein is the most highly expressed. The $71 \mathrm{kDa}$ protein is associated with ORF 71, at nucleotide positions 43,231 to 45,099 , and putatively consists of 622 amino acid residues. The theoretical molecular weight of the ORF 71 product is $68.5 \mathrm{kDa}$, which is close to the $71 \mathrm{kDa}$ major protein band observed by SDS-PAGE.

The one-step growth curve of $\Phi C S 01$ revealed that the latent period is $60 \mathrm{~min}$, and that it takes $80 \mathrm{~min}$ after infection to complete the burst, with a burst size of $90.7 \mathrm{pfu}$ (plaque-forming units)/infected cell (Fig. 2B). Compared with C. sakazakii phage PBES02, the latency period of ФCS01 is $30 \mathrm{~min}$ longer, the time to complete the burst is 5 min longer, and the burst size is 159.3 pfu smaller [12].

To test the stability of $\Phi C S 01$ when exposed to various environmental conditions, phage stability was assessed at a range of temperatures and $\mathrm{pH}$ levels (Figs. 2C and 2D). When incubated at $4-37^{\circ} \mathrm{C}$ for $1 \mathrm{~h}$, $\Phi C S 01$ was stable, with decreased infectivity at $50-60^{\circ} \mathrm{C}$. In contrast, the samples lost infectivity after incubation for $1 \mathrm{~h}$ at $70^{\circ} \mathrm{C}$. Therefore, a temperature range of $4-37^{\circ} \mathrm{C}$ was found to be the optimal 
Table 1. Annotation of ORFs found in $\Phi C S 01$ genome.

\begin{tabular}{|c|c|c|}
\hline ORF No. & Encoded phage protein & Function \\
\hline CS01_01 & Tail fiber protein [Cronobacter phage ESP2949-1] & Structure \\
\hline CS01_02 & Tail assembly protein [Cronobacter phage ESP2949-1] & Structure \\
\hline CS01_03 & Tail assembly protein [Salmonella phage phSE-5] & Structure \\
\hline CS01_04 & Minor tail protein [Cronobacter phage ESP2949-1] & Structure \\
\hline CS01_05 & Minor tail protein [Cronobacter phage ESP2949-1] & Structure \\
\hline CS01_06 & Tail tape-measure protein [Cronobacter phage ESP2949-1] & Structure \\
\hline CS01_07 & TfmS [Salmonella phage FSL SP-126] & Additional function \\
\hline CS01_09 & Major tail protein [Cronobacter phage ESP2949-1] & Structure \\
\hline CS01_18 & Major head subunit precursor [Cronobacter phage ESP2949-1] & Structure \\
\hline CS01_19 & Phage head morphogenesis protein [Cronobacter phage ESP2949-1] & Structure \\
\hline CS01_20 & Portal protein [Cronobacter phage ESP2949-1] & DNA packaging \\
\hline CS01_21 & Terminase large subunit [Cronobacter phage ESP2949-1] & DNA packaging \\
\hline CS01_22 & Terminase small subunit [Cronobacter phage ESP2949-1] & DNA packaging \\
\hline CS01_34 & ATP-binding protein [Cronobacter phage ESP2949-1] & Replication and regulation \\
\hline CS01_43 & Polynucleotide kinase [Cronobacter phage ESP2949-1] & Replication and regulation \\
\hline CS01_49 & gp76 [Escherichia phage Tls] & Additional function \\
\hline CS01_53 & Site-specific DNA methylase [Cronobacter phage ESP2949-1] & Replication and regulation \\
\hline CS01_58 & RzlA [Cronobacter phage ESP2949-1] & Additional function \\
\hline CS01_59 & Endolysin [Cronobacter phage ESP2949-1] & Host lysis \\
\hline CS01_65 & Dam methylase [Cronobacter phage ESP2949-1] & Replication and regulation \\
\hline CS01_68 & ATP-dependent helicase [Cronobacter phage ESP2949-1] & Replication and regulation \\
\hline CS01_69 & Transcriptional regulator [Cronobacter phage ESP2949-1] & Replication and regulation \\
\hline CS01_70 & DNA primase [Cronobacter phage ESP2949-1] & Replication and regulation \\
\hline CS01_71 & Tail fiber [Cronobacter phage ESP2949-1] & Structure \\
\hline CS01_72 & Single-stranded DNA binding protein [Cronobacter phage ESP2949-1] & Replication and regulation \\
\hline CS01_73 & RecT [Cronobacter phage ESP2949-1] & Additional function \\
\hline CS01_75 & Exodeoxyribonuclease [Cronobacter phage ESP2949-1] & Replication and regulation \\
\hline
\end{tabular}

condition for ФCS01 storage. ФCS01 would be a suitable antimicrobial agent for this industrial application because finished PIF products are not exposed to temperatures over $70^{\circ} \mathrm{C}$ after production or during storage at room temperature [12].

In the $\mathrm{pH}$ stability test, infectivity persisted after exposure to $\mathrm{pH}$ 4-11 for more than $1 \mathrm{~h}$. On the other hand, when exposed to $\mathrm{pH} 1-3$ or $\mathrm{pH}>11$, infectivity was lost. In general, phages are stable at a $\mathrm{pH}$ range of 5 to 9 . Usually, no viable phage particles are detected after incubation at $\mathrm{pH} 11.8-14$ or $\mathrm{pH}<2$ [26].

\section{Genome Analysis}

The double-stranded (ds)DNA ФCS01 genome consists of 48,195 bases, with a G+C content of $50.11 \%$ (GenBank Accession No. MH845412) (Fig. 3A). Open reading frame
(ORF) analysis revealed that this genome contains 75 genes (Table 1). Twenty-seven ORFs were annotated, including nine genes associated with replication and regulation, ten genes related to structural proteins, three genes associated with DNA packaging, one gene related to host lysis, and four genes associated with other functions. Analysis of 75 ORFs did not reveal allergenic or toxin-related proteins.

A Basic Local Alignment Search Tool (BLAST) search of GenBank revealed the most similar phage was ESP2949-1 (accession number JF912400.1) [27] and indicated that the two phages have $98 \%$ identity from $97 \%$ coverage of nucleotide sequence. The two phage genomes were compared by Mauve analysis (Fig. 3B).

The whole dsDNA genome of phage ESP2949-1 contains 49,116 bases and 43 ORFs. The genome of CCS01 is 921 base pairs shorter but contains 32 more ORFs than that of 
A
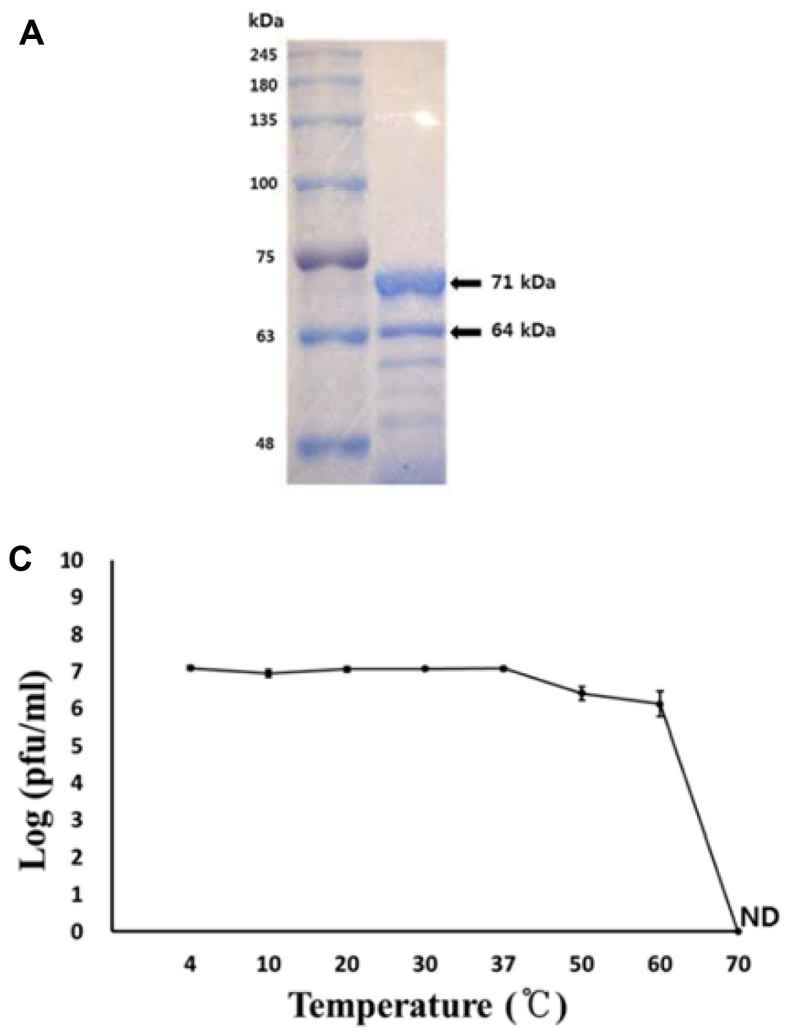
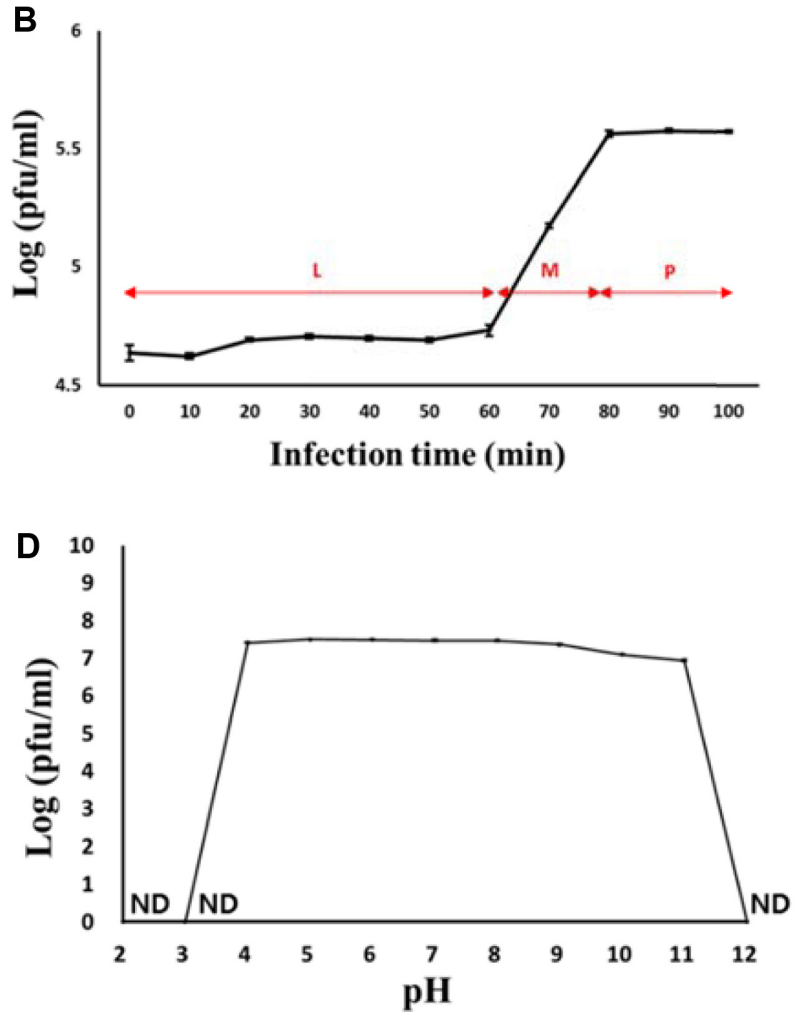

Fig. 2. Molecular characterization of $\Phi C S 01$.

(A) SDS-PAGE analysis of major $\Phi C S 01$ proteins. (B) One-step growth of $\Phi \mathrm{CS} 01$ at $0.1 \mathrm{MOI}, 37^{\circ} \mathrm{C}$ (L: latent phase, M: maturation phase, P: plateau phase. (C) Stability of $\Phi C S 01$ after exposure to various temperatures, and (D) stability of $\Phi C S 01$ after exposure to various pH levels. ND: not detected.

ESP2949-1. Because ESP2949-1 has not yet been biologically characterized, comparisons other than those based on genome analysis are currently impossible. The genome lengths, similarities, and the number of ORFs suggest that ESP2949-1 and ФCS01 phages may have a common ancestor.

\section{Phylogenetic Analysis}

Phylogenetic analysis involving genomic DNA sequences (registered in GenBank) of 18 genes encoding major capsid proteins of Cronobacter phages revealed 100\% agreement with the capsid protein of C. sakazakii phage ESP2949-1 (Fig. 4). The phylogenetic tree was built with 500 bootstrap repetitions in MEGA 6. This finding suggests that the two phages are evolutionarily closely related and indicates that the ФCS01 phage may have an infection mechanism similar to that of ESP2949-1.

\section{Host-Range Test}

The host specificity of $\Phi C S 01$ was examined with 12 different species (Table 2). ФCS01 infected only C. sakazakii.
Table 2. Host-range test for phage CS01.

\begin{tabular}{lcc}
\hline \multicolumn{1}{c}{ Bacteria } & Strain No. $^{\mathrm{a}}$ & Susceptibility $^{\mathrm{b}}$ \\
\hline $\begin{array}{l}\text { Cronobacter sakazakii } \\
\text { (formerly Enterobacter sakazakii) }\end{array}$ & ATCC 29544 & + \\
Enterobacter sp. & ATCC 21754 & - \\
Enterobacter asburiae & ATCC 35956 & - \\
Enterobacter pyrinus & KCTC 2590 & - \\
Enterobacter aerogenes & KCTC 2190 & - \\
Enterobacter cloacae & ATCC 13047 & - \\
Bacillus subtilis & ATCC 9372 & - \\
Bacillus cereus & ATCC 14579 & - \\
Lactobacillus plantarum & ATCC 14917 & - \\
Staphylococcus aureus & ATCC 25923 & - \\
Escherichia coli & ATCC 25922 & - \\
Shigella flexneri & KCTC 2998 & - \\
\hline
\end{tabular}

${ }^{\mathrm{a}} \mathrm{ATCC}$, American Type Culture Collection; KCTC, Korean Collection for Type Cultures.

${ }^{\text {bS }}$ usceptibility was determined by measuring plaque formation. 


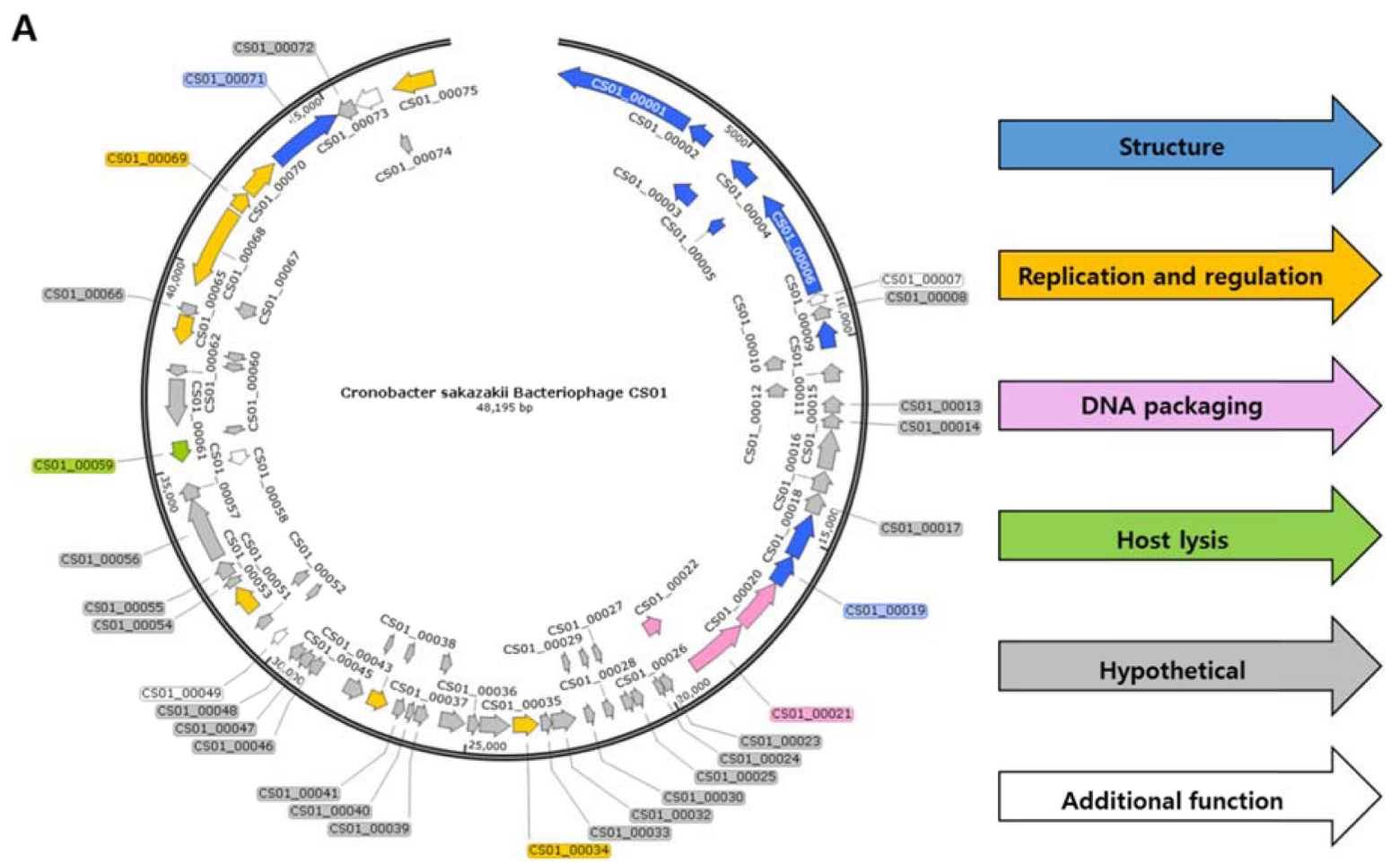

B

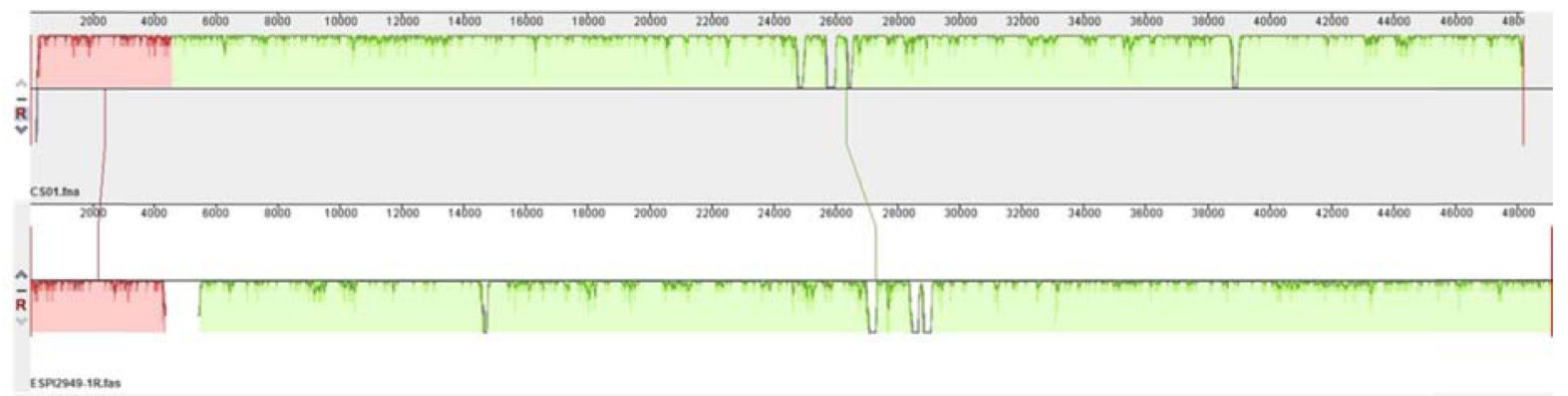

Fig. 3. Schematic representation of the whole $\Phi C S 01$ dsDNA genome.

(A) Putative ORFs are represented by arrows, with predicted functions when available. Proposed modules are based on predicted functions. Blue: structural protein; yellow: replication and regulation; pink: DNA packaging; green: host lysis; gray: hypothetical protein; white: additional function. (B) Mauve analysis of genomic DNA from ФCS01 (upper) and ESP2949 (lower).

In contrast, ФCS01 is an Enterobacter sp. (KCTC 2625), Enterobacter asburiae (KCTC 23920), Enterobacter pyrinus (KCTC 2590), Enterobacter aerogenes (ATCC 13048), Enterobacter cloacae (KCTC 2361), Bacillus subtilis (ATCC 9372), Bacillus cereus (ATCC 14579), Lactobacillus plantarum (ATCC 14917), Staphylococcus aureus (ATCC 25923), Escherichia coli (ATCC 25922) and Shigella flexneri (KCTC 2998) were not infected. These results suggest that the $\Phi C S 01$ has the ability to infect C. sakazakii from Enterobacter species, and is an expected biological control agent suitable for $C$. sakazakii.

Use of bacteriophages as biocontrol agents is a promising method for controlling pathogenic bacteria including antibiotic-resistant bacteria. Bacteriophages are applicable as safe bactericides for the elimination of pathogens. In this study, the stability of the bacteriophage $\Phi C S 01$ was evaluated at various temperatures and $\mathrm{pH}$ levels, and onestep growth behavior was assessed. Molecular and genetic characteristics of $\Phi C S 01$ were assessed by SDS-PAGE (sodium dodecyl sulfate-polyacrylamide gel electrophoresis) and genome analysis. Our results indicate that ФCS01 has high potential for application as a biocontrol agent against food borne pathogens. 


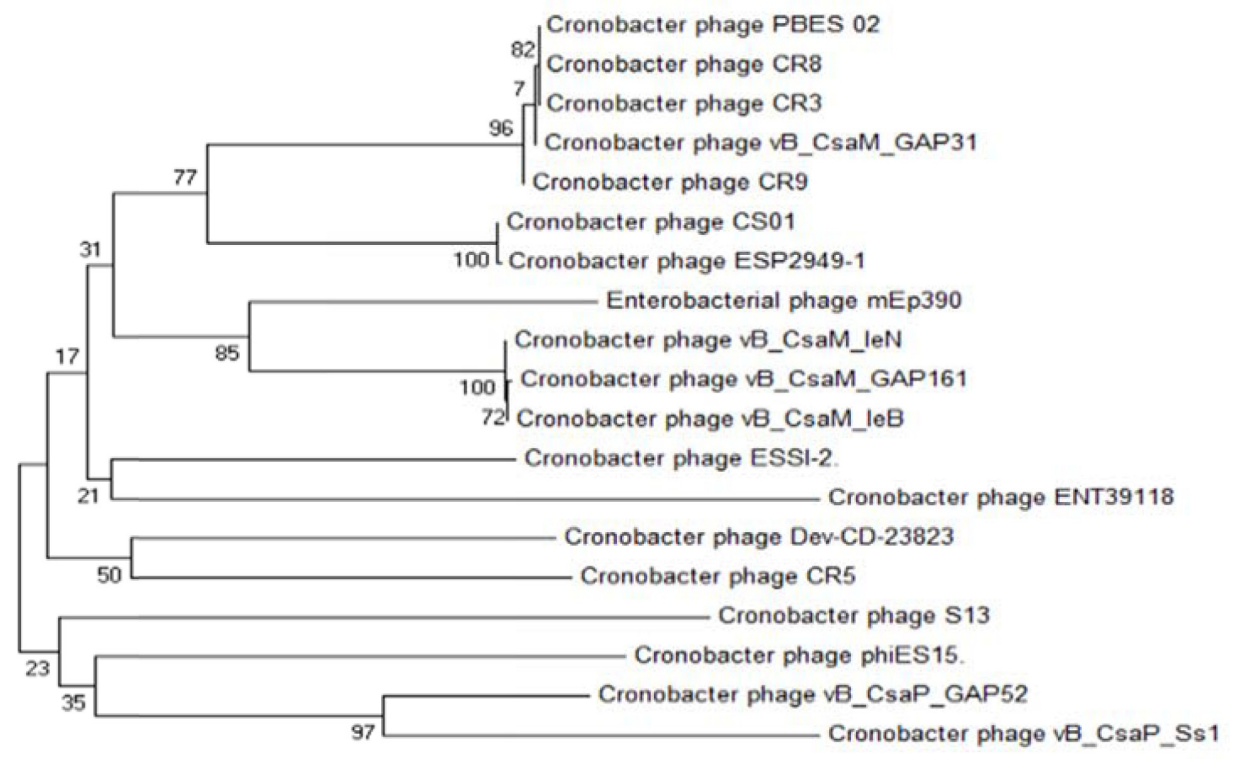

Fig. 4. Phylogenetic tree based on the major capsid protein sequences from 18 different phages that infect Cronobacter.

In this study, a bacteriophage capable of infecting C. sakazakii, ФCS01, was isolated and characterized. Our findings suggest that $\Phi C S 01$ could be used as an alternative to antibiotics for use against antibiotic-resistant bacteria, and our stability test results suggest that $\Phi C S 01$ is suitable for industrial application in PIFs for controlling C. sakazakii contamination. Our results highlight the stability of ФCS01 and its potential for applications to promote food safety in the food and PIF industries.

\section{Acknowledgments}

This study was funded by a grant of the National Research Foundation of Korea (2015R1D1A1A01058374).

\section{Conflict of Interest}

The authors have no financial conflicts of interest to declare.

\section{References}

1. Yan QQ, Condell O, Power K, Butler F, Tall BD, Fanning S. 2012. Cronobacter species (formerly known as Enterobacter sakazakii) in powdered infant formula: a review of our current understanding of the biology of this bacterium. J. Appl. Microbiol. 113: 1-15.

2. Mofokeng L, Cawthorn DM, Witthuhn RC, Anelich LECM, Jooste PJ. 2011. Characterization of Cronobacter species
(Enterobacter Sakazakii) isolated from various South African food sources. J. Food Safety 31: 98-107.

3. Osaili TM, Shaker RR, Ayyash MM, Al-Nabulsi AA, Forsythe SJ. 2009. Survival and growth of Cronobacter species (Enterobacter sakazakii) in wheat-based infant followon formulas. Lett. Appl. Microbiol. 48: 408-412.

4. Greer GG. 2005. Bacteriophage control of foodborne bacteria. J. Food Protect. 68: 1102-1111.

5. Cai XQ, Yu HQ, Ruan ZX, Yang LL, Bai JS, Qiu DY. 2013. Rapid detection and simultaneous genotyping of Cronobacter spp. (formerly Enterobacter sakazakii) in powdered infant formula using real-time PCR and high resolution melting (HRM) analysis. PLos One 8: e67082.

6. Liu X, Fang JH, Zhang MZ, Wang XY, Wang WF, Gong YF. 2012. Development of a loop-mediated isothermal amplification assay for detection of Cronobacter spp. (Enterobacter sakazakii). World J. Microbiol. Biotechnol. 28: 1013-1020.

7. Lou XQ, Si GJ, Yu H, Qi JJ, Liu T, Fang ZG. 2014. Possible reservoir and routes of transmission of Cronobacter (Enterobacter sakazakii) via wheat flour. Food Control. 43: 258-262.

8. Xu X, Wu Q, Zhang J, Ye Y, Yang X, Dong X. 2014. Occurrence and characterization of cronobacter spp. In powdered formula from chinese retail markets. Foodborne Pathog. Dis. 11: 307-312.

9. Kalatzis PG, Castillo D, Katharios P, Middelboe M. 2018. Bacteriophage interactions with marine pathogenic vibrios: implications for phage therapy. Antibiotics-Basel. 7(1) pii: E15.

10. Kumari S, Harjai K, Chhibber S. 2010. Evidence to support the therapeutic potential of bacteriophage Kpn5 in burn wound infection caused by Klebsiella pneumoniae in BALB/c mice. J. Microbiol. Biotechnol. 20: 935-941. 
11. Lee JH, Bai J, Shin H, Kim Y, Park B, Heu S, et al. 2016. A novel bacteriophage targeting cronobacter sakazakii is a potential biocontrol agent in foods. Appl. Environ. Microbiol. 82: 192-201.

12. Lee, HJ, Kim WI, Kwon YC, Cha KE, Kim M, Myung H. 2016. A Newly Isolated Bacteriophage, PBES 02, Infecting Cronobacter sakazakii. J. Microbiol Biotechnol. 26: 1629-1635.

13. Abbasifar R, Kropinski AM, Sabour PM, Ackermann HW, Alanis VA, Abbasifar A, et al. 2012. Genome sequence of Cronobacter sakazakii myovirus vB_CsaM_GAP31. Am. Soc. Microbiol. 86: 13830-13831.

14. Abbasifar RAM, Kropinski PM, Sabour HWA, Lingohr EJ, Griffiths MW. 2012. Complete genome sequence of Cronobacter sakazakii bacteriophage vB_CsaM_GAP161. J. Virol. 86: 13806-13807.

15. Lee YD, Chang HI, Park JH. 2011. Complete genomic sequence of virulent Cronobacter sakazakii phage ESSI-2 isolated from swine feces. Arch. Virol. 156: 721-724.

16. Lee YD, Park JH. 2012. Complete genome of temperate phage ENT39118 from Cronobacter sakazakii. J. Virol. 86: 5400-5401.

17. Kajsík M, Bugala J, Kadličeková V, Szemes T, Turňa J, Drahovská H. 2019. Characterization of Dev-CD-23823 and Dev-CT57, new Autographivirinae bacteriophages infecting Cronobacter spp. Arch. Virol. 1-9.

18. Lee JH, Choi Y, Shin H, Lee J, Ryu S. 2012. Complete genome sequence of Cronobacter sakazakii temperate bacteriophage phiES15. J. Virol. 86: 7713-7714.

19. Kazi M, Annapure US. 2016. Bacteriophage biocontrol of foodborne pathogens. J. Food Sci. Tech. Mys. 53: 1355-1362.

20. Rodriguez L, Martinez B, Zhou Y, Rodriguez A, Donovan DM, Garcia P. 2011. Lytic activity of the virion-associated peptidoglycan hydrolase HydH5 of Staphylococcus aureus bacteriophage vB_SauS-philPLA88. BMC Microbiol. 11.

21. Lee HJ, Kim WI, Kwon YC, Cha KE, Kim M, Myung H. 2016. A newly isolated bacteriophage, PBES 02, infecting Cronobacter sakazakii. J. Microbiol. Biotechnol. 26: 1629-1635.

22. Simoliunas E, Kaliniene L, Stasilo M, Truncaite L, Zajanckauskaite A, Staniulis J, et al. 2014. Isolation and characterization of vB_ArS-ArV2-First Arthrobacter sp. infecting bacteriophage with completely sequenced genome. PLos One 9.

23. Alves DR, Gaudion A, Bean JE, Esteban PP, Arnot TC, Harper DR, et al. 2014. Combined use of bacteriophage K and a novel bacteriophage to reduce Staphylococcus aureus biofilm formation. Appl. Environ. Microbiol. 80: 6694-6703.

24. Linderoth NA, Julien B, Flick KE, Calendar R, Christie GE. 1994. Molecular-cloning and characterization of bacteriophage$\mathrm{P} 2$ gene- $\mathrm{R}$ and gene-S involved in tail completion. Virology 200: 347-359.

25. Cao ZH, Zhang JC, Niu YD, Cui NZ, Ma YS, Cao F. 2015. Isolation and characterization of a "phiKMV-like" bacteriophage and its therapeutic effect on mink hemorrhagic pneumonia. PLos One 10.

26. Jończyk E, Kłak M, Międzybrodzki R, Górski A. 2011. The influence of external factors on bacteriophages. Folia Microbiol. 56: 191-200.

27. Lee JH, Choi Y, Shin H, Lee J, Ryu S. 2012. Complete genome sequence of Cronobacter sakazakii temperate bacteriophage phiES15. J. Virol. 86: 7713-7714.

28. Lee YD, Kim JY, Park JH, Chang H. 2012. Genomic analysis of bacteriophage ESP2949-1, which is virulent for Cronobacter sakazakii. Arch. Virol. 157: 199-202. 